\title{
A Preliminary Investigation Into the Use of Edible Fishery By-products as Sources of Nutrients for Fish and Livestock Feeds on Zanzibar, Tanzania
}

\author{
J.M. Akil ${ }^{1}$, M.J. Bryant ${ }^{2}$, N.S. Jiddawi ${ }^{3}$ \\ ${ }^{1}$ Ministry of Agriculture, Natural resources, Environment and Cooperatives, P.O. Box 159, Zanzibar, \\ Tanzania; ${ }^{2}$ Department of Agriculture, School of Agriculture, Policy and Development, The University of \\ Reading, P.O. Box 237, Reading RG6 6AR, UK; ${ }^{3}$ Institute of Marine Sciences - University of Dar es Salaam, \\ P.O. Box 668, Zanzibar Tanzania
}

Key words: Fish waste, nutrients, fish and livestock feeds

\begin{abstract}
A survey, to measure the quantity of edible fish waste (gills and guts) available per year, was conducted on Unguja Island, Zanzibar between December 2003 and February 2004. Seventeen samples from commercially important fish genera and species were collected from five landing sites ('dikos') in five districts of the Island, dissected and the amount of wastes quantified as percentage of individual body weights. Reliable data on annual catches (tonnage) of the selected species or genera were used to extrapolate total amounts of fish waste produced. Separate samples (gills and guts) were isolated and treated as (1) boiled and sun dried and (2) sun dried without boiling; and analyzed to determine fat (EE g/100gDM), mineral (ash g/100gDM) and protein $(\mathrm{CPg} / 100 \mathrm{gDM})$. In addition, bulky fish wastes (mixed gills+guts) were collected from the same sites, boiled, sun dried and stored for further feeding trials and duplicate samples analyzed. Results show percentage fish waste $(\% \mathrm{Ww})$ between individual genera and species varied significantly $(10.47 \pm 0.93 ; \mathrm{P}<0.001)$. Average annual fish waste produced is $2.040 \mathrm{t}$ out of total 1.84, 1.81, 1.79 and 2.72 thousand tonnes from the years 2001, 2002, 2003 and 2004 catches respectively. The body parts of fish significantly determined fat and mineral composition $(\mathrm{LSM}$ for gills $=10.85 \pm 1.486 \mathrm{~g} / 100 \mathrm{gDM}$ EE vs. guts $=15.45 \pm 1.486 \mathrm{~g} / 100 \mathrm{gDM} \mathrm{EE} ; \mathrm{P}=0.033$ and LSM for gills $=23.49 \pm 1.494 \mathrm{~g} / 100 \mathrm{gDM}$ mineral vs. guts $=14.27 \pm 1.494 \mathrm{~g} / 100 \mathrm{gDM}$ Ash; $\mathrm{P}<0.001$ ), while treatment (boiling at $95-105^{\circ} \mathrm{C}$ ) had no effect on both fat, protein and mineral. Significant variation in overall protein content between species $(\mathrm{LSM}=57.68 \pm 2.33 ; \mathrm{P}<0.001)$ is observed. Slight dispersions between sites for mineral ( $\mathrm{LSM}=29.1 \pm 2.01 \mathrm{~g} / 100 \mathrm{gDM})$ and fat $(\mathrm{LSM}=13.93 \pm 1.05 \mathrm{~g} / 100 \mathrm{~g} \mathrm{DM})$ showed up in bulky wastes. It was concluded that valuable quantity of fish waste is available to reduce the limiting protein supplementation problem in both livestock and fish farming in the western Indian Ocean region. However, additional on-station and on-farm studies are required to measure the intakes and effects of the supplement on milk yields and growth performances.
\end{abstract}

\section{INTRODUCTION}

The high costs and seasonal inadequacy of feeds are collectively the most limiting factors in the performance of the livestock industry in developing countries (Makkar, 2000) and indeed, in both semi-intensive and intensive aquaculture (Lim et al., 1997).

Diverse methods used to preserve fish waste to be used in animal feeding systems are widely practiced. These may include cooking fish and pressing the cooked mass to remove most of the 
oil and water (McDonald et al., 2002) or preserving the by-catch (scrap, heads and offal) in the form of silage (Smith, 1977). However, despite the high demand for protein and other nutrients for livestock and aquaculture, little work has been done on the use of the by-product on the Zanzibar islands.

Reported here are the results of a preliminary survey conducted on Zanzibar between December 2003 and February 2004, aimed at the quantification of the annual edible fish waste (gills and guts) produced and the determination of their macronutrient contents; protein, fat and ash. The long-term objective of the study was to create opportunity for the development of new feeding packages for livestock keepers and aqua-culturists in the WIO region; a particular emphasis being widening the use of fish waste as an important animal feed resource in the area.

Further to this survey, other on-station and on-farm studies are being conducted to measure the intake, digestibility, nitrogen balance and production performance in dairy cows. Discussions to extend the use of the fish waste in the fish diets at Makoba fish farm in Zanzibar are underway.

\section{METHODOLOGY}

\section{Sample collection sites}

Sample collection was done in five landing sites "dikos" of the island of Unguja, Zanzibar - namely from: Kizimkazi, Mazizini, Malindi, Chwaka and Mkokotoni (Figure 1) between December 2003 and February 2004.

\section{Measurement of the annual available fish waste}

- Fish dissection and calculation of percentage wastes per species:

Each of the 17 commercially important fish species or genera on the islands was dissected and weighed to obtain the total body weights (Tw) and the corresponding edible wastes (Ww) (gills+guts). The percentage fish wastes were calculated as follows:

$$
(\% \mathrm{Wsp} 1)=\frac{\mathrm{Ww} 1}{\mathrm{Tw} 1} \times 100
$$

\section{Where:}

$\% \mathrm{Wsp} 1=$ Percentage waste from species 1

Ww1 = Weight of fish wastes from species1

Tw1 = Total weight of fish $($ species 1$)$

- Extrapolation of the annual fish waste harvests based on the total annual catches $(\mathrm{kg})$ of each of the 17 species, was as follows:

$\% \mathrm{Wsp} 1 \times \mathrm{Tc} 1$

\section{Where:}

Tc $1=$ Total catches $(\mathrm{kg})$ of specie 1 per year

- Calculation of the total wastes produced per year, was based on:

$\Sigma \mathrm{Ww} 1+\mathrm{Ww} 2$ Wwn

\section{Chemical composition of the edible fish wastes}

- Separation of samples from body parts (gills and guts) of the selected fish species and genera were treated as follows:

(i) Un-boiled + Sun dried

(ii) Pre-boiled (at $95-105^{\circ} \mathrm{C}$ for $10-15$ minutes) + Sun dried

- Random sampling of the pre-boiled (at 95 $-105^{\circ} \mathrm{C}$ ) and sun-dried bulk fish waste (gills+guts) from selected areas "dikos" in five Districts of Unguja Island.

- Laboratory analysis on samples for dry matter $(\mathrm{DM})$, crude protein $(\mathrm{CP})$, fat (EE) and mineral content (as described by Pilgrim, 1999; Pearson, 1976; and ATA Website respectively).

\section{Statistical analysis}

The raw data from the fish waste yield and chemical composition were entered and stored in Microsoft Excel for Windows ${ }^{\circledR}$ XP Professional which provided computation facility required before imported to statistical software for analysis. 


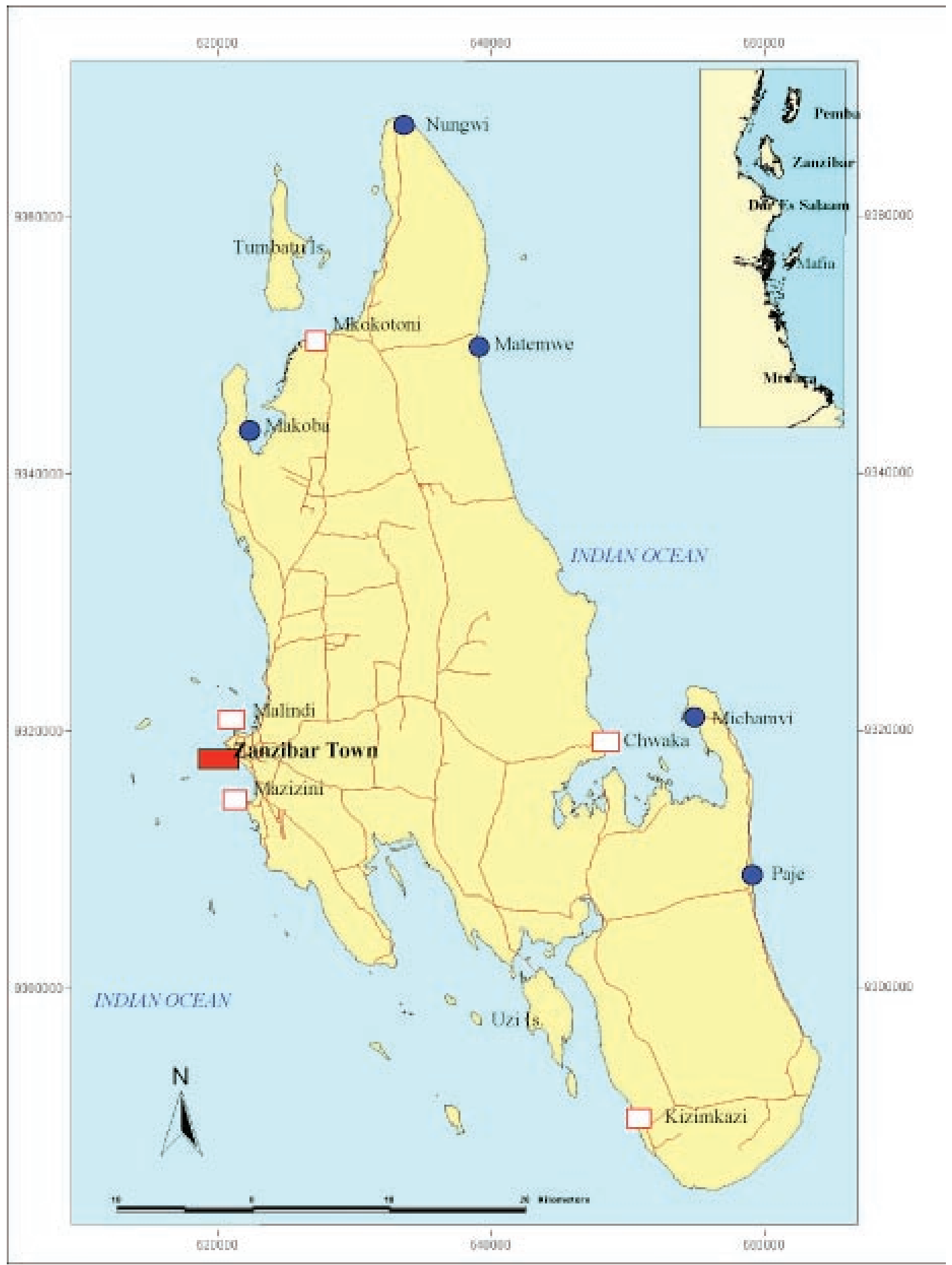

Fig. 1. Locations of sample collection sites and Zanzibar along the Tanzania coast 
Independent factors; body part and treatment were used to investigate variability of the chemical composition between the samples. The analysis of variance was used to analyse the data according to the General Linear Model procedure of the Minitab Statistical Package (Release 14, 2005).

\section{RESULTS}

\section{Percentage wastes produced from individual fish species}

The percentages of fish waste yields ( $\% \mathrm{Ww})$ of the identified species varied significantly $(10.47 \pm 0.93$; $\mathrm{P}<0.001)$ from the least (3.82) to the highest (17.69) species (Table 1).

Table1. Percentage fish waste yields from individual species

\begin{tabular}{llrc}
\hline $\begin{array}{l}\text { Fish species } \\
\text { (with local names) }\end{array}$ & $\begin{array}{c}\text { Av. Waste } \\
\text { yields } \\
(\%)\end{array}$ & $\begin{array}{c}\text { Av. Gills: } \\
\text { Guts ratio } \\
\text { (kg) }\end{array}$ \\
\hline 1 & Gerres spp. ('chaa') & 10.23 & $1: 1.6$ \\
2 & Nemipterus spp. ('koana') & 10.77 & $1: 2.1$ \\
3 & Lutjanus fulviflamus & 10.03 & $1: 2.6$ \\
4 & Lethrinus spp. & 9.67 & $1: 1.8$ \\
5 & Lutjanus argentimaculatus & 15.92 & $1: 4.3$ \\
6 & Epinephelus chlorostigma & 10.25 & $1: 2$ \\
7 & Sphyraena spp & 11.97 & $1: 4.1$ \\
8 & Auxis tapeinosoma & 17.69 & $1: 2.1$ \\
9 & Scomberomorus commerson & 5.84 & $1: 2.1$ \\
10 & Carangoides spp. ('kolekole') & 14.06 & $1: 2.6$ \\
11 & Upeneus sulphurous & 8.08 & $1: 1.8$ \\
12 & Hipposcarus spp. & 3.82 & $1: 1.8$ \\
13 & Rastrelliger kanagurta & 12.05 & $1: 1.6$ \\
14 & Stolephorus spp. ('saadini') & 9.09 & $1: 2.6$ \\
15 & Sardinella spp. & 8.07 & $1: 2.8$ \\
16 & Caesio caeralaureus & 5.06 & $1: 1.6$ \\
17 & Siganus spp. & 15.42 & $1: 8.2$ \\
18 & Other demersal/pelagic spp. & 9.66 & - \\
\hline
\end{tabular}

\section{Annual fish waste yields}

Four years of catch data records (2001 - 2004) show an average annual catch of 22,773.6t corresponding to $2,040.1 \mathrm{t}$ of the fish waste produced. However, in the most recent year (2004), a sharp increase of approximately $6,503 \mathrm{t}$ and $676 \mathrm{t}$ above average of the fish catch and fish waste yield respectively were observed (Figure 2).

\section{Chemical composition of the body parts}

The body part of the fish (gills or guts) is a significantly determining factor for mineral, as shown in Table 2, $($ gill $=23.49 \pm 1.494$, gut $=$ $14.27 \pm 1.494 ; \mathrm{P}<0.001$ ) and fat (gill $=10.85 \pm 1.486$, gut $=15.45 \pm 1.486 ; \mathrm{P}<0.05)$ composition $(\mathrm{g} / 100 \mathrm{~g}$ DM) in fish. Treatment (boiling) had no influence on the amount of protein, fat and mineral contained in the sample.

Table 2. Least Square Mean for body parts and treatment

\begin{tabular}{llccc}
\hline & & $\begin{array}{c}\text { CP(g/ } \\
\text { 100g DM) }\end{array}$ & $\begin{array}{c}\text { EE(g/ } \\
\mathbf{1 0 0 g} \text { DM) }\end{array}$ & $\begin{array}{c}\text { Mineral } \\
\text { g/100g } \\
\text { DM })\end{array}$ \\
\hline \multirow{5}{*}{ Body part } & & & & \\
& Gills & 57.42 & 10.85 & 23.49 \\
& Guts & 59.84 & 15.45 & 14.27 \\
& SEM & 2.039 & 1.486 & 1.494 \\
& P-Value & 0.404 & 0.033 & $<0.001$ \\
& & & & \\
Treatment & Boiling & 59.65 & 12.85 & 17.90 \\
(boiling) & No boiling & 57.62 & 13.45 & 19.86 \\
& SEM & 2.039 & 1.486 & 1.494 \\
& P-Value & 0.484 & 0.778 & 0.357 \\
\hline
\end{tabular}

$\mathrm{CP}=$ Crude Protein, $\mathrm{DM}=$ Dry Matter, $\mathrm{EE}=$ Ether Extracts

\section{Species variation in overall protein content}

An overall protein content $(\mathrm{g} / 100 \mathrm{~g} \mathrm{DM})$ of the identified species varied significantly $(57.68 \pm 2.33$; $\mathrm{P}<0.001$ ), with the lowest and highest levels being CP 37.52 and $70.98 \mathrm{~g} / 100 \mathrm{~g}$ DM respectively (Figure 3).

\section{Chemical composition of the bulky fish wastes from five landing sites of Zanzibar}

There are no significant variations between five collection sites in terms of protein (Table 3), although a slight dispersion from means is observed in ash $(29.1 \pm 2.01)$ and fat $(13.93 \pm 1.05)$ content $(\mathrm{g} / 100 \mathrm{~g}$ DM) of fish. 


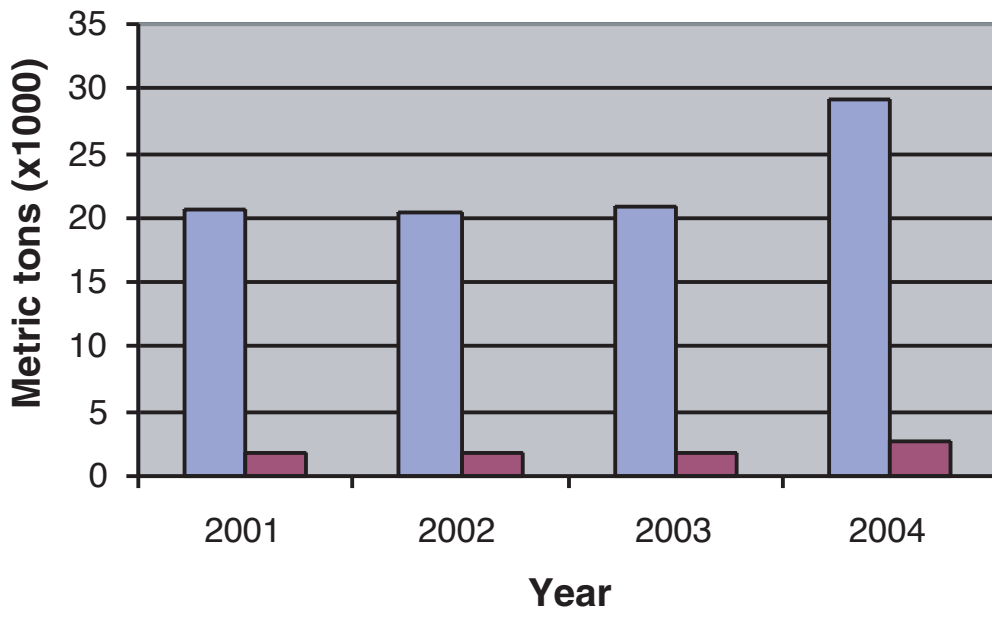

\section{$\square$ Total catches \\ $\square$ Total fish waste}

Data source: Department of Fisheries and Sea Products, Zanzibar (2004))

Fig. 2. Annual fish catch and fish waste yield (2001-2004)

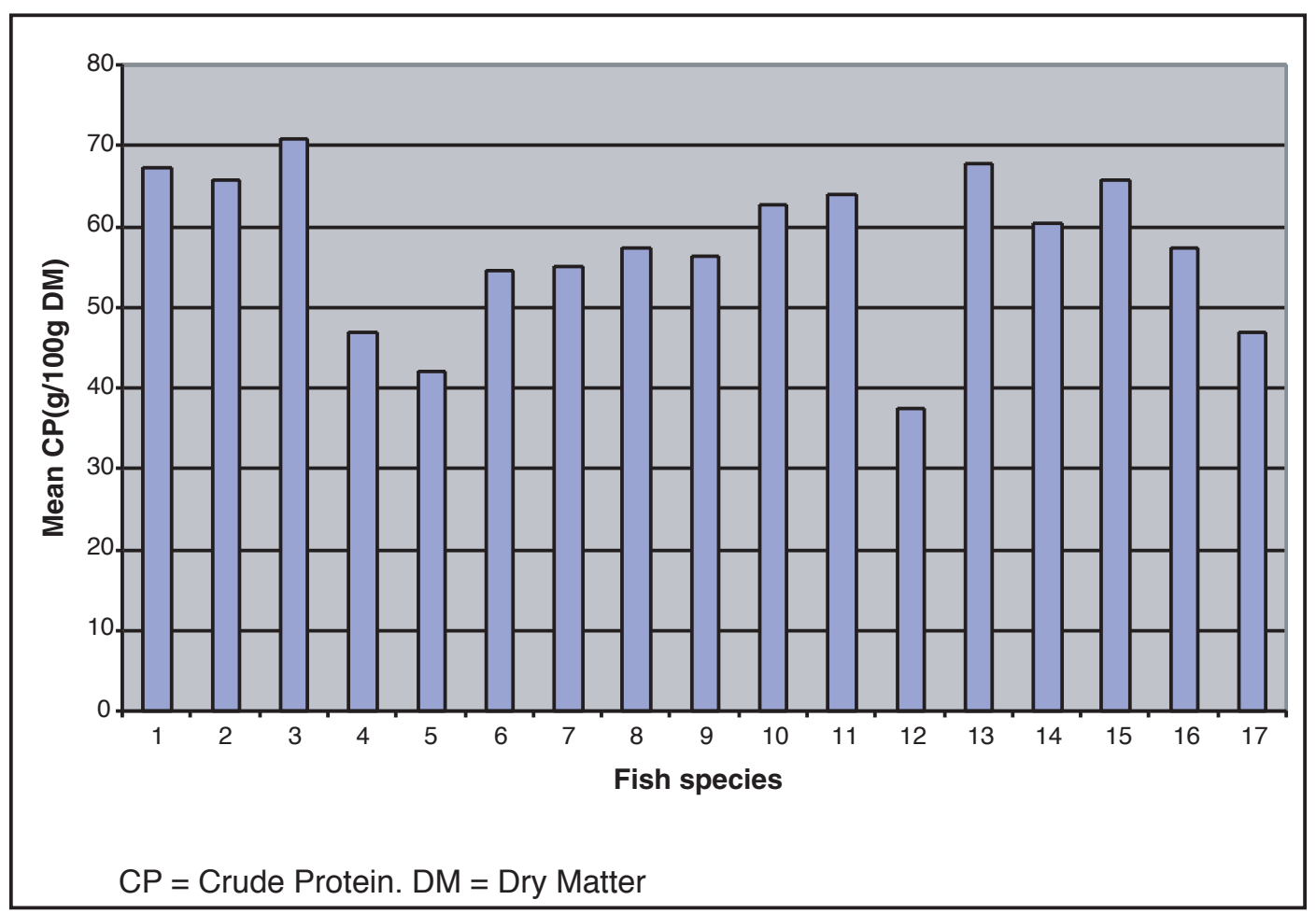

Fig. 3. Average protein content from individual fish species 
Table 3. Nutrient composition of the fish waste from five landing sites

\begin{tabular}{lccc}
\hline $\begin{array}{l}\text { Landing Site } \\
\text { ('diko') }\end{array}$ & $\begin{array}{c}\text { Av. CP } \\
\text { (g/100gDM) }\end{array}$ & $\begin{array}{c}\text { Av. EE } \\
\text { (g/100gDM) }\end{array}$ & $\begin{array}{c}\text { Av. Mineral } \\
\text { (g/100g DM) }\end{array}$ \\
\hline Kizimkazi & 53.54 & 16.04 & 24.89 \\
Chwaka & 52.66 & 9.96 & 35.65 \\
Mkokotoni & 59.21 & 14.55 & 25.85 \\
Mazizini & 51.77 & 13.94 & 31.69 \\
Malindi & 55.25 & 15.15 & 27.41 \\
Mean & $\mathbf{5 4 . 4 9}$ & $\mathbf{1 3 . 9 3}$ & $\mathbf{2 9 . 1}$ \\
SEM & $\mathbf{1 . 3 1}$ & $\mathbf{1 . 0 5}$ & $\mathbf{2 . 0 1}$ \\
\hline
\end{tabular}

$\mathrm{CP}=$ Crude Protein, $\mathrm{DM}=$ Dry Matter, $\mathrm{EE}=$ Ether Extracts

\section{DISCUSSIONS AND CONCLUSION}

Variation in percentage waste weights between fish species is due to the differences in their body sizes and the internal organs (FAO, 1985). The compact body, fleshiness and proportionally small offal size of Hipposcarus species, rendered it the lowest fish waste yielder. In contrast, other species such as Auxis tapeinosoma, Lutjanus argentimaculatus and Siganus spp. had a relatively high proportion of the fish waste yield.

A fairly constant fish catch trend is evident from year 2001 through 2003. However, a sharp increase is observed in the year 2004, whereby an improved marine conservation strategy which includes strict prohibition and replacement of the destructive fishing gears, education of fishermen, enhanced record keeping and improved management of the landing sites "dikos" in recent years is expressed as a major reason (DFSP pers com., 2005). The amount of correspondingly fish waste produced also reached its highest quantity in 2004.

From the results (Section 3.3 above), a clear reciprocal relationship between fat and ash content in gills and guts exists. While the main reason for high ash content in gills $(>10-22 \%)$ as estimated by McDonald et al. (2002) is thought to be the presence of supporting "gills arches" containing high proportion of calcium and phosphorous and a number of desirable minerals including manganese, iron and iodine (Mc Donald et al. 2002), a high concentration of fat in the liver of the herrings and lean fish (FAO, 1986) is probably a major contributing factor for a high fat content in guts.
The little effect of treatment (boiling at $95-105^{\circ} \mathrm{C}$ ) on the amount of fat, protein and mineral would in turn have advantage of reducing histamine problem in fish, without affecting the quality of the meal (Reyes et al., 1991). According to this author a timely heating prevents the decomposition process that influence the histamine production in fishmeal. A relatively short heating time $(10-15$ minutes $)$ is also less likely to cause any adverse effect on digestibility and protein quality (Mc Donald et al., 2002).

Although the study reported here showed no significant variation in protein content between the three major fish groups, extremes were observed between the carnivorous e.g. Lutjanus fulviflamus (70.98g/100g DM) and herbivores e.g. Hipposcarus spp. (37.52 g/100g DM), most probably due to the influence of the gut contents present during sampling.

As discussed in the above section, the amount of ash and fat are highly dependent on the proportions of gill and gut contained in the sample. Variations between the gill:gut ratios of different species landed are probably a major contributing factor for the differences observed between the two chemical components.

A considerable amount of fish waste is exploitable on Unguja Island and indeed other areas within the western Indian Ocean region. This seems a sustainable and cheap animal by-product that can best be utilized as source of protein in both livestock and fish farming in the area. However, the use of fish waste may be limited by a number of factors mainly associated with collection of the fish waste, timely processing and quality control. In this regard, further studies are needed to measure and control microbiological spoilage and oxidation of lipids during handling by fishermen, and in transport and sun drying. The results also beg for further investigations on the utilization of fish waste as source of nutrients for fish and livestock feeds.

Acknowledgement-We would like to thank all fishermen and fish vendors who gave their time to this work. Our thanks are also due to Project staff: Mr. J.O. Ali, A.H. Suleiman, I.A. Silima and Ms. R. Abubakar, M.I. Balozi and others who helped collect the data. We acknowledge the support of the International Atomic Energy Agency, Vienna, 
who helped fund the work through Technical Co-operation Project C3-URT/5/021 "Livestock Development in Zanzibar after Tsetse Eradication", the Ministry of Agriculture, Natural resources, Environment and Cooperatives - Zanzibar and the University of Reading for their facilitation on this piece of work.

\section{REFERENCES}

ATA. http://www.aquaculture.ugent.be/ATA/analysis/ ash.htm Analysis of feed and feed ingredients, Proximate analysis. Analytical Techniques in Aquaculture Research.

DFSP- Department of Fisheries and Sea products, Zanzibar, Tanzania. Personal Communication (July 2005).

FAO (1985) Food and Agricultural Organization. Field guide to the Commercial and brackish-water Species of Tanzania.

FAO (1986). The Fisheries Industries Division (1986). The production of fishmeal and oil p. 63. FAO Fisheries Technical Papers - T142

Lim C., Beamen R.M., Eales J.G, Prendergast A.F, Mc Leese J.M, Shearer K.D, and Higgs, D.A (1997).
Nutritive values of low and high fibre canola meals for shrimp (Penaeus vannamei). Aquaculture Nutrition 1997; pp 269 - 279. (C) 1997 Blackwell Science Ltd.

Makkar, H.P.S (2000). - Development and field evaluation of animal feed supplementation packages. Proceedings of the final review meeting of an IAEA TC Regional AFRA Project - Joint IAEA/FAO Division.

McDonald, P., Edward, R.A., Greenhalgh, J.F.D., Morgan, C.A (2002). Animal Nutrition (sixth edition). pp 601 - 604.

Pearson, D. (1976). The Chemical Analysis of Foods.

Pilgrim R., (1999). Kjeldahl Nitrogen Determination using Buechi System. NSRU Chemistry \& Biochemistry Laboratory, Dept. of Agriculture.

Reyes G., Martinez R., Rodriguez L.M., Bello R.A., Cruz-Pascual M., (1991). Effect of the addition of tropical fruit wastes on the rate of production of microbial silage from fish. http://www.fao.org/ag/ AGA/AGAP/FRG/AFRIS/Absts/13. HTM.

Smith, P. (1977). An evaluation of liquid fish as a protein source for fattening pigs. J. Exp. Husbandry. 32: 34 - 41. 